\title{
Financial and legal measures to support small and medium-sized businesses in the context of pandemic turbulence
}

\author{
Yulia Lobanova ${ }^{1}$, Ilya Aminov ${ }^{1, *}$ \\ Moscow Polytechnic University, 38 Bolshaya Semyonovskaya Str., 107023, Moscow, Russia
}

\begin{abstract}
The article reveals the consequences of the coronavirus crisis for business activity in Russia. The article considers certain financial and legal measures to prevent economic losses for small and medium-sized enterprises (SMEs) taken by the Russian authorities in the context of a long and devastating COVID-19 pandemic. It was revealed that one of the effective financial and legal mechanisms for overcoming a difficult socioeconomic situation is the National Guarantee System for Supporting Small and Medium-Sized Businesses (NGS) created in the Russian Federation back in 2014 and intensified its comprehensive activities in the context of pandemic turbulence. The directions and principles of NGS activity are analyzed. Additional measures to support SMEs have been disclosed due to announcement of another lockdown in Russia in the fall of 2021. The directions for further improvement of the system of state support for small and medium-sized businesses are outlined, such as the renewal of credits at zero rates on salaries, the establishment of a "grace" period and preferential interest rates for credit repayment, tax debts cancellation, subsidizing loans subject to the hiring of new personnel, compensation of rent, taxes and comprehensive rehabilitation programs. It is concluded that it is necessary to take measures to minimize the threat of declaring lockdowns in the future.
\end{abstract}

\section{Introduction}

The coronavirus epidemic everywhere and seriously changed the international, social and business life, the daily routine of every person. Against the background of pandemic turbulence, the prospect of the beginning of the epoch of tectonic shifts in all spheres of life has arisen [1].

Amid the protracted coronavirus marathon, there has been a global economic downturn. Business has found itself in a difficult condition due to the constant and general increase in world prices, prices from suppliers, prices for raw materials, for utilities, services and transport services. Even deep import substitution is not able to stop this process [2]. Real inflation for the year amounted to $30-40 \%$ for almost all categories of goods, including cars and building materials [3]. This was superimposed with another trend - a fall in purchasing

*Corresponding author: aminovii@mail.ru 
power. Russians began to earn less and, accordingly, consume less. Demand for many services has dropped. People began to spend only on the essentials. In Russia, after the abolition of self-isolation in June 2020, every fifth business did not open [4]. The widespread online commerce and e-service offer only limited support, but do not compensate for all the global losses incurred.

Small and medium-sized enterprises (SMEs), namely, those industries that are forced to stand idle for several months are especially hard during a pandemic. Among them: agricultural cooperation, restaurant business, beauty salons, fitness clubs, travel agencies, car repair shops. The impact of self-isolation on small and medium-sized businesses turned out to be one of the main blows to the real economy [5]. Decrease in the cash turnover of enterprises providing services to the population per day averages $25-30 \%$, and in some industries and regions it can reach an even higher percentage. SMEs are now being liquidated much more often than new ones are being created. Many of these businesses are being transformed into the form of self-employment of citizens or simply disappear into the shadows [6].

In these conditions, the state cannot stand aside and must respond in a timely and effective manner by adopting constructive and stabilizing measures.

\section{Methods}

In the course of the study, we used such specific scientific methods of cognition as formal legal, comparative legal, structural, and systemic.

\section{Study Results}

In the fall of 2021, Russian business was hit by the fourth wave of the coronavirus crisis. Against the background of a sharp deterioration in the epidemiological situation, Russian President V.V. Putin announced a non-working day regime in the country from October 30 to November 7 with salary retention ${ }^{1}$. In Moscow, where the number of cases exceeded all previous records, a lockdown was introduced, including for businesses and enterprises ${ }^{2}$, by the decree of the mayor of the capital S.S. Sobyanin from October 28 to November 7. The exception was the sale of medicines, food and other essential goods. Distance selling of goods was not limited, as were the work of restaurants and cafes to take away and the delivery of ready-made meals. Similar measures, when enterprises in the sphere of trade and services, sports, culture, recreation, entertainment, film screenings, and others are compulsorily closed, were taken in five more constituent entities of the Russian Federation. Despite the fact that the autumn lockdown of 2021 was not a surprise to anyone and, despite the "hardening" received in the previous lockdowns, many representatives of SMEs were practically on the verge of survival due to impending inevitable losses and even the threat of a complete cessation of activities. Even in conditions of more lenient measures than total lockdown, during the period when QR codes were introduced in Moscow in public catering, the average daily drop was almost $35 \%$.

Supporting business amid the coronavirus epidemic, along with supporting the population, has become one of the main tasks of the Russian authorities. Analyzing the

\footnotetext{
${ }^{1}$ Decree of the President of the Russian Federation of October 20, 2021 No. 595 "On the Establishment of Non-Working Days in the Territory of the Russian Federation in October - November of 2021" // URL: Official Internet portal of legal information http://pravo.gov.ru, October 20, 2021

${ }^{2}$ Decree of the Mayor of Moscow dated October 21, 2021 No. 62-UM "On Amendments to the Decree of the Mayor of Moscow No. 68-UM dated June 8, 2020" // Official portal of the Mayor and the Government of Moscow http://www.mos.ru, October 21, 2021.
} 
efforts of the Government made within the previous waves of the coronacrisis, it can already be argued that the Russian authorities have managed to support millions of entrepreneurs.

The issue of supporting small businesses is always relevant, and during the ongoing pandemic, it can play a decisive role in the economic development of the country [7]. On January 1, 2021, the Order of the Ministry of Economic Development of Russia No. 586 dated September 09, 2020 came into force, which approved the "Basic Provisions for Development of the National Guarantee System (NGS) for Supporting Small and MediumSized Businesses for the Period until 2024". Small business representatives can safely count on receiving preferential credits, as well as refinancing existing ones, guarantees and sureties, including for participation in purchases and when concluding a lease agreement.

The national guarantee system is a three-tier system of organizations interacting with each other, providing credit and guarantee support to small and medium-sized businesses on the basis of uniform standards. It was created back in 2014 as a financial and legal mechanism for implementation of the Strategy for the Development of Small and Medium Enterprises in the Russian Federation until 2030. The national guarantee system includes the Corporation for the Development of Small and Medium Enterprises (SME Corporation), SME Bank JSC and regional guarantee organizations (RGO).

One of the main problems for small and medium-sized enterprises is insufficient collateral for obtaining a credit, as well as high interest rates. In this regard, the SME Corporation coordinates the activities of the participants in the national guarantee system to provide guarantees and (or) independent guarantees. To this end, the Corporation conducts an annual ranking of SME organizations with the assignment of a rank characterizing the degree of their financial stability and efficiency. Given this rank, the state provides financial support to such enterprises. The SME Corporation issues guarantees for large projects - from 100 million rubles. SME Bank provides guarantees for credits up to 100 million rubles. The RGS issues guarantees for small credits.

It shall be noted that SMEs, as a rule, are not very enthusiastic about applying for credits from commercial banks, as they believe that borrowing at current rates is the way to ruin and feed banks only. Accordingly, the national guarantee system provides special, constantly decreasing credit and loan rates for some business projects. Therefore, the weighted average rate on credits and loans issued to SMEs with participation of the NGS in 2015 amounted to $16.91 \%$, in $2019-9.13 \%$, that is, it is below the market level. For all credits issued in 2020, the weighted average rate was $8.2 \%$ per annum [7]. Self-employed citizens who apply a special tax regime in the form of paying tax on professional income may also apply for this support.

For the convenience and timeliness of obtaining a credit, an automated information system (AIS) has been developed for managing applications of SMEs applying for financial support within the framework of the NGS. In addition, today, online interaction has been arranged between financial institutions, NGS participants and borrowers - SMEs in order to provide credit and guarantee support and operational support for implementation of the subsidy program provided for by the Decree of the Government of the Russian Federation of December 30, 2018, No. 1764 "On Approval of the Rules for Provision of Subsidies from the Federal Budget to the Russian Credit Institutions for Reimbursement of Lost Income on Credits Issued in 2019-2024 to Small and Medium-Sized Businesses at the Preferential Rate". There are subsidy programs implemented by the Ministry of Economic Development, as well as other government programs for which it is possible to get credits or loans with a small percentage.

A target product line aimed at meeting a wide range of SMEs needs has been formed, including:

- basic guarantee products for investment, circulating financing, co-guarantees with the Russian Geographical Society; 
- guarantee products for financing SMEs - procurement participants;

- for SMEs operating in priority territories (including the territories of the Far Eastern Federal District, North Caucasian Federal District);

- for support infrastructure organizations;

- for SMEs within implementation of anti-crisis measures.

Tools have been created to expand the access of micro and small enterprises to financial and guarantee support, including by reducing the average amount of independent guarantees and sureties issued within the framework of the NGS.

Important aspects of the activities of one of the subjects of the national guarantee system - SME Bank - are also implementation of market mechanisms for refinancing SME credit portfolios of commercial banks using mechanisms for securitizing credits provided to SMEs, as well as participation in development of stock market instruments for use by SMEs in order to gain access to additional sources of funding.

To provide opportunities for lending the SMEs in all constituent entities of the Russian Federation directly by the SMEs, the Bank has formed a regional network for sale of creditguarantee products by arranging the remote work of employees, as well as attracting partner organizations to promotion of such products.

In general, the activities of the NGS participants ensure provision of financial support to the SMEs, the consolidated volume of which includes:

- credits, loans provided to SMEs secured by independent guarantees and sureties of the NGS participants;

- obligations under bank guarantees issued for the obligations of the SMEs;

- obligations of the SMEs to redeem bonds placed on the stock exchange and pay coupon income on them;

- monetary liabilities (or liabilities in monetary terms) of the SMEs under agreements, contracts concluded within the framework of procurement in accordance with Federal Law of July 18, 2011, No. 223-FZ "On Procurement of Goods, Works, Services by Certain Types of Legal Entities" and Federal Law dated April 05, 2013, No. 44-FZ "On the Contract System in the Field of Procurement of Goods, Works, Services to Meet State and Municipal Needs"; - monetary obligations under financial lease (leasing) agreements, financing agreements against the assignment of a monetary claim (factoring agreements), investment agreements using investment platforms in accordance with Federal Law dated August 02, 2019, No. 259FZ "On Attracting Investments Using Investment Platforms and on Amendments to Certain Legislative Acts of the Russian Federation";

- monetary obligations under transactions involving other financing.

The main direction of the NGS development for the period 2021-2024 is to further increase the volume of credit and guarantee support in order to expand the access of the SMEs to concessional financing in order to implement the federal project "Expanding the Access of the SMEs to Financial Resources, Including Concessional Financing of the National Project, as well as Achievement of Indicators (Parameters) of the National Project and the Subprogram "Development of Small and Medium-Sized Enterprises" of the State Program of the Russian Federation "Economic development and innovative economy".

Key priorities for the NGS development are:

- simplifying the access of recipients of guaranteed support to financial support measures with an emphasis on providing such support to the SMEs operating in priority areas of the economy;

- improving the conditions for financing the recipients of guarantee support within the framework of the NGS, including by reducing the interest rate on a credit (loan), the cost of leasing services, factoring, other financing for the final recipient of financial support, reducing the average size of independent guarantees and sureties for micro- and small businesses. 
The priority categories of recipients of support include women, youth, entrepreneurs over 45 , persons with disabilities and others.

Within the framework of such interaction, depending on the profile and needs of the applicant, targeted credit guarantee products for target client segments can be formed.

Interaction of information systems of the NGS participants is aimed at reducing the time for consideration of applications and making a credit guarantee decision, as well as the support chosen by the applicant using these services and the AIS.

\section{Discussion of Results}

Within the global crisis of 2008-2013, economists Kenneth Rogoff and Carmen Reinhart wrote a famous book with an ironic title for that time "This Time Will Be Different: Eight Centuries of Financial Stupidity" [8]. In their paper, the authors substantiated the position that all crises are similar to each other. However, in an interview with the American financial information agency Bloomberg in May 2020, they warned that the coronavirus crisis is still very different from past crises [9]. It will no longer be possible to use the experience gained then as a template for solving problems. This means that in the current conditions it is necessary to look for new effective methods to overcome the economic recession, when all efforts of states shall be aimed at maintaining and preserving the economy, business and population [10].

In this regard, despite a certain readiness of Russian entrepreneurs for various scenarios for development of a pandemic situation and the "hardening" they received during the coronavirus marathon, the Ministry of Economic Development of Russia timely responded to announcement of new anti-epidemiological restrictions in the country and announced measures to support the SMEs from November 1 to December 2021.

First of all, we are talking about credits under the FOT 3.0 program (wage fund). This benefit is intended for the SMEs that operate in established industries: sports organizations and fitness centers, sanatoriums, travel agencies, hotels, catering establishments, cinemas, museums, zoos, as well as businesses that arrange leisure, recreation, entertainment and events. The program will also affect young businesses opened in the period from July 1, 2020, as well as large catering and cultural enterprises that participated in previous programs of the Wage Fund. The key condition of the program is to keep the number of employees at a level of at least $90 \%$. Credits will be issued at $3 \%$ per annum. More than 30 banks accredited under the program participate in the program. Credits up to RUB 300 million. with state guarantees are planned to be issued for up to 18 months. Wherein, during the first 6 months, the entrepreneur is exempted from paying the credit and interest on it, and over the next 12 months he/she will be able to return the credit and interest in equal shares.

In addition, the Government of the Russian Federation guarantees accrual of a one-time payment in the form of a gratuitous grant for a one-time compensation of wages to employees during a lockdown. The amount of support is determined depending on the number of employees at the rate of 1 minimum wage for each employee. For individual entrepreneurs without hired workers, 1 minimum wage is also required. These grants are issued on an online application or an application by mail to the local tax authority. However, this measure will not affect those who work piece-rate, under civil contracts.

The SMEs which work in the sports, hospitality, catering, additional education for children and adults, consumer services, culture, leisure and entertainment, museums, dental offices, hairdressing salons, beauty salons and some others will be able to apply for a gratuitous grant. In total, there are 21 positions in the list of industries whose representatives can receive a grant.

Wherein, the federal measures of state support will be supplemented by regional ones, depending on the situation in a particular subject and the specifics of local business. 


\section{Conclusions}

In conclusion, we can say that the pandemic has caused serious damage to business and the economy as a whole. According to experts, the coronavirus will pose a danger for a long time. Although the Government quickly developed the first emergency measures of support, back in March 2020, the list of sectors of the economy affected by the epidemic is growing, and we still cannot talk about a complete recovery of small and medium-sized businesses. The Russian government is currently working on a course to rehabilitate the SMEs' business activity, such as renewing credits at zero rates on wages, establishing a grace period and preferential interest rates for credit repayments, writing off tax debts, subsidizing loans on condition of hiring new personnel, compensation for rent, taxes and a number of other programs. Support measures are certainly good. However, the entrepreneur does not need any support measures and subsidies, if he/she ends up sitting in a lockdown or serving people using QR codes only. It is important for an entrepreneur that there are no more lockdowns. It is in this general direction that one shall move.

\section{References}

1. V. V. Putin, Vystuplenie Prezidenta Rossii na zasedanii diskussionnogo kluba «Valdaj» (2021). Access mode: http://www.kremlin.ru/events/president/news/64261

2. I. F. Kolontaevskaya, L. E. Zavedeeva, Organizational and legal enforcement of digital economy in the Russian Federationat the present stage, Sustainable Development: Society, Ecology, Economy: Proceedings of the XVth International Scientific Conference, 153-157 (2019)

3. A. Gornyj, Biznes, govorite? Luchshe ih proest', chem poteryat' (2021). Access mode: https://echo.msk.ru/blog/amountain/2927196-echo/

4. A. Romanenko, «Deneg net»: pochemu kazhdyj pyatyj biznes v Rossii ne otkrylsya posle samoizolyacii (2020). Access mode: https://www.forbes.ru/karera-i-svoybiznes/405443-deneg-net-pochemu-kazhdyy-pyatyy-biznes-v-rossii-ne-otkrylsya-posle

5. A. V. Epanchinceva, Mery podderzhki malogo i srednego biznesa v Rossii v period pandemii koronavirusa: kriticheskij analiz, Ekonomika novogo mira, 1-2(17), 17-22 (2020)

6. M. R. Gapov, D. K. Hubieva, Predprinimatel'stvo v period pandemii, Moskovskij ekonomicheskij zhurnal, 9, 125-154 (2020)

7. A. P. Tishin, Nacional'naya garantijnaya sistema podderzhki malogo i srednego predprinimatel'stva, Aktual'nye voprosy buhgalterskogo ucheta i nalogooblozheniya, 5, 66-73 (2021)

8. C. M. Reinhart, K. Rogoff, This Time Is Different: Eight Centuries of Financial Folly (2009)

9. S. Kennedy, Harvard's Reinhart and Rogoff Say This Time Really Is Different (2020). Access mode: https://www.bloomberg.com/news/features/2020-05-18/harvard-sfinancial-crisis-experts-this-time-really-is-different

10. N. S. Stepanov, Pochemu ne rabotayut institucional'nye mekhanizmy podderzhki malogo i srednego predprinimatel'stva v usloviyah pandemii (koronavirusnoj infekcii), Biznes. Obrazovanie. Pravo, 3 (52), 243-247 (2020) 